\title{
Responses of Maize Landrace Seedlings to Inoculations of Fusarium spp.
}

\author{
Dolores Briones-Reyes ${ }^{1}$, Fernando Castillo-González ${ }^{2}$, Carlos de León-García-de-Alba ${ }^{3}$, \\ Antonio Ramírez-Hernández², Víctor Heber Aguilar-Rincón'², José Luis Chávez-Servia ${ }^{4}$
}

\author{
${ }^{1}$ Instituto Nacional de Investigaciones Forestales Agrícolas y Pecuarias-CE Pabellón, Pabellón de Arteaga, Aguascalientes, Mexico \\ ${ }^{2}$ Postgrado en Recursos Genéticos y Productividad-Genética, Colegio de Postgraduados, Montecillo, Mexico \\ ${ }^{3}$ Postgrado en Fitosanidad-Fitopatología, Colegio de Postgraduados, Montecillo, Mexico \\ ${ }^{4}$ Instituto Politécnico Nacional, CIIDIR Unidad Oaxaca, Santa Cruz Xoxocotlán, Mexico \\ Email: *jchavezs@ipn.mx
}

How to cite this paper: Briones-Reyes, D., Castillo-González, F., de León-García-deAlba, C., Ramírez-Hernández, A., AguilarRincón, V.H. and Chávez-Servia, J.L. (2017) Responses of Maize Landrace Seedlings to Inoculations of Fusarium spp. Open Access Library Journal, 4: e3687.

https://doi.org/10.4236/oalib.1103687

Received: May 23, 2017

Accepted: June 17, 2017

Published: June 20, 2017

Copyright $\odot 2017$ by authors and Open Access Library Inc.

This work is licensed under the Creative Commons Attribution International License (CC BY 4.0).

http://creativecommons.org/licenses/by/4.0/

\section{(c) (i) Open Access}

\begin{abstract}
To assess the reaction of maize landrace seedlings to inoculations of Fusarium spp. derived from different geographic origins, inoculations were performed to substrates in which seeds were germinated, and the severity of damage and the degree of resistance and/or tolerance at the seedling stage were later evaluated. In this study, 57 populations of maize were collected in the states of Oaxaca, Puebla, Tlaxcala, Guerrero and Estado de Mexico, Mexico, and at same time five sources of Fusarium spp. inoculum were obtained. The maize collection and inocula were then evaluated in a bi-factorial arrangement of treatments in a randomized complete block design with four replications. Significant differences were observed in the virulence of the isolates from each geographic region $(p<0.01)$. The inoculum consisting of isolates from Estado de Mexico proved to be the most virulent, whereas the inoculum from the state of Guerrero caused the least amount of damage to maize seedlings. The length of the roots and aerial portions of the seedlings were reduced due to the effect of the pathogen in comparison with seedlings that emerged in the substrate without inocula. The maize populations responded differently to the pathogen depending on its geographic origin, as the maize plants expressed different amounts of damage caused by the various inocula to which they were subjected. No direct relationship was observed between the virulence of the inoculum and the resistance/tolerance to the disease of populations from the same origin; in some cases, such as that of Tlaxcala, pathogens of the same origin caused more damage to maize from that region.
\end{abstract}

\section{Subject Areas}

Agricultural Science 


\section{Keywords}

Zea mays L., Fusarium spp., Virulence, Resistance, Pathosystem

\section{Introduction}

Fusarium species synthesize various mycotoxins that represent a high risk for human and animal health because Fusarium species have cancerogenic effects (e.g., Fusarium verticillioides); in cultivated maize, these species cause rot in seedlings, roots, stems and ears and, consequently, cause a considerable reduction in grain yields [1] [2] [3] [4]. Therefore, the production of mycotoxins in maize by Fusarium is a worldwide problem wherever maize is used for human consumption or for livestock feed.

Mexico is the origin, domestication and center of diversity of maize. Culturally, maize is the most important crop in economic terms due to its cultivated area of approximately eight million hectares and in social terms because maize is the main food for human consumption via a wide variety of dishes and derivate products of the agroindustry [5] [6]. The largest cultivated area is under rain-fed conditions with a short and irregular distribution of precipitation $(>80 \%$ of total area); this area is planted mainly with seeds of landraces or autochthonous varieties reproduced by the farmers themselves (>70\%) [7] [8]. Despite landrace populations being highly adaptable, they have a number of problems; the most visible is damage to ear rot caused by Fusarium spp. [9].

Fusarium fungi cause root and stem rot and premature death of seedlings as well as ear and stem rot in adult plants, causing $23 \%$ to $30 \%$ losses in yields [10] [11] [12]. Until a few years ago, the species Fusarium verticillioides and F. graminearum were reported to be the principal problems; however, in several countries where maize is grown, the presence of a wide variety of species of $\mathrm{Fu}$ sarium has been shown to be infecting stems and ears [13] [14]. This finding has occurred in Africa, where the introduction of maize was relatively recent [15]. The damage from Fusarium not only affects yield but also produces fumonisins, zearalenone and other mycotoxins that are harmful to human and animal health [16] [17] [18]. In China, the presence of esophageal cancer has been associated with eating maize contaminated with Fusarium toxins [1].

Maize seeds and seedlings can be directly invaded by Fusarium spp., which have been found in the pericarp and internal layers of the kernels, and the presence of this fungus in the soil can cause systemic infections of the root and stem, seedling blight and accumulation of toxins [10] [19] [20]. The sowing of maize in soils with a high moisture content and low temperature increases the presence of kernel rot and/or blight in the seedlings [21]. The severity of damage varies based on other causes to the species, virulence of the pathogen and levels of resistance/tolerance in maize genotypes [22].

Maize research has been oriented towards distinguishing the levels of resistance to ear rot caused by $F$. graminearum or F. verticillioides, however, it has 
not yet been possible to identify any type of genetic action that could guide the selection of resistant genotypes. For example, inheritance of resistance is reported as being of the additive type, with possible non-additive effects, digenic or dominant, as well as polygenic. In spite of these difficulties, resistance to two or more species of Fusarium is not common but has been observed in some cases [23] [24] [25]. Recently, using QTLs, some regions with small effects that contribute to resistance have been identified and validated [14] [26].

In spite of progress made in the identification of the sources of resistance, it should be mentioned that in each agroecological niche, maize landraces coexist with species of Fusarium spp. with varying degrees of virulence and are not always those same species used to evaluate resistance. In addition, mutualist interactions of maize populations-Fusarium spp. (plant-pathogen) exist in Mexico and in every village where maize is cultivated, likely due to coevolution between the species [27] [28] [29]. In this context, variation in the virulence of isolates of Fusarium spp. and the susceptibility or resistance of the seedlings of native maize populations in response to inoculation of Fusarium spp. from different geographic locations in south-central Mexico was evaluated.

\section{Materials and Methods}

\subsection{Maize Germplasm}

In 2010, a sample of 30 to 40 visibly healthy cobs (with no kernel rot) was collected from 57 populations of native maize in the states of Oaxaca, Puebla, Tlaxcala, Guerrero and Estado de Mexico, Mexico. To complement this sample, a homologous sample of ears with visible damage caused by Fusarium spp., such as streaks on the kernel pericarp and/or salmon/pink-reddish-colored mycelia, was included. Of the total samples gathered, only 33 were homologous to the healthy populations sampled, and monoconidial isolates were obtained from those samples (Table 1). To represent each state with isolates from the same number of locations, seven isolates were chosen randomly that had been identified morphologically as F. verticillioides, F. graminearum or F. subglutinans, and a physical mixture was made to be inoculated that represented the state of origin.

Table 1. Geographic origin of 57 maize landrace populations and 33 Fusarium spp. isolates from the south-central region of Mexico.

\begin{tabular}{ccccc}
\hline \multirow{2}{*}{ State } & $\begin{array}{c}\text { Municipalities of origin from the } \\
\text { population of maize and isolates }\end{array}$ & $\begin{array}{c}\text { Altitude range } \\
(\text { masl })\end{array}$ & \multicolumn{2}{c}{ No. samples } \\
\cline { 4 - 5 } Tlaxcala & Ixtacuixtla, Españita, Nanacamilpa, Totolac & $2220-2720$ & 12 & 7 \\
Guerrero & Chilapa, Cualac, Tixtla, Zitlala. & $1498-2222$ & 13 & 7 \\
Puebla & Xochitlán, Libres. & $1610-2400$ & 6 & 7 \\
Oaxaca & Huamelulpan, Tayata, Peñasco, Tataltepec, & $2144-2290$ & 13 & 7 \\
Estado de & Ticua & & & 73 \\
Mexico & Ayapango, Chalco, Tepetlixpa, Texcoco. & $2249-2450$ & 13 & 7 \\
\hline
\end{tabular}




\subsection{Increase of Inoculum}

Monoconidial isolates of Fusarium spp. were grown separately in Petri dishes filled with potato dextrose agar medium (PDA). Subsequently, a massive increase of the inoculum was made using whole oat grains that had previously been soaked for four hours and sterilized in an autoclave ( 2 hrs. at $20 \mathrm{psi}$ ) as substrate. After the sterile substrate had cooled, a square of PDA from each isolate per state was incubated at room temperature under natural light for three weeks until the substrates were fully colonized.

\subsection{Virulence Evaluation of Isolates and the Severity of Damage to Seedlings}

Maize populations were sown in 0.5-L Styrofoam containers filled with a mixture of $1: 1.5$ or $40: 60 \%(\mathrm{v} / \mathrm{v})$ of oat substrate colonized by the isolates $\left(1.6 \times 10^{6}\right.$ conidia $\mathrm{g}^{-1}$ ) and with sterilized black soil. A bi-factorial arrangement of treatments was established: five groups of isolates from the states of Estado de Mexico, Puebla, Tlaxcala, Guerrero and Oaxaca plus a control with no inoculum (factor A) and 57 populations of maize (factor B) distributed in a randomized complete block design with four replications. Ten maize seeds per population were used in each experimental unit. The trial was conducted in greenhouse conditions during the months of August to October 2012 in the facilities of the Colegio de Posgraduados at Texcoco, Mexico.

The evaluation of the severity of damage to the foliage area and stem of the maize seedlings was made 30 days after planting based on the scale proposed by Solano-Báez [30] where 1 = healthy plant, 2 = plant reduced in size, 3 = seedling with chlorosis and/or blight damage, $4=$ seedling with upward-curling foliage, and $5=$ dead seedling or showing more than $90 \%$ foliage damage. The seedlings were then removed from the substrate in order to record the length and weight of the roots; length and weight of the seedlings or aerial portion; and total fresh and dry weight of the seedling with the roots. The weighted average of foliage damage was calculated according to the following formula (Equation (1)):

$$
\text { Weighted average of damage }(\bar{Y})=\left(X_{1} \times Y_{1}+X_{2} \times Y_{2}+\cdots+X_{5} \times Y_{5}\right) / T
$$

where $X_{i}=$ number of seedlings in each category of the scale, $Y_{j}=$ value of the scale, and $T=\left(X_{1}+X_{2}+\ldots+X_{5}\right)$, the total number of seedlings in each experimental unit.

\subsection{Statistical Analysis}

With the information gathered, a database was formed of the treatments and variables evaluated. Then, in order to prove the differences among inocula, maize populations and the inocula-maize population interactions, analyses of variance were performed under the experimental design and complemented with multiple means comparisons using Tukey's tests $(p \leq 0.05)$. All the analyses were performed using SAS statistical software [31]. 


\section{Results}

High variation was observed in the degree of damage to seedlings from maize populations in response to inoculation of Fusarium spp. isolates from different geographic origins, and the grade of damage was an indicator of different degrees of virulence. The seedlings showed symptoms whose intensity varied from delay in growth, yellowing of leaves, and less root length to inhibition or delay in seed germination as part of the pathogenic effect in comparison with the control plants that showed normal growth without visual damage in terms of the evaluation scale. Significant differences were determined $(p<0.05)$ among maize populations (Po) and among sources of Fusarium spp. inocula (In) for all variables recorded (Table 2).

\subsection{Virulence of the Pathogen by Geographic Origin}

All isolates caused various degrees of damage to maize seedlings. In the comparison of inoculum sources (Figure 1), significant differences were recorded based on variables related to the severity of damage, root and seedling dimensions and seedling weight. The Fusarium spp. isolates that caused major damage correspond to samples of inocula collected in the southeastern region from the State of Mexico; in particular to this study, these inocula were considered the most virulent ones because they caused the most damage to seedlings and decreased the length of roots and aerial portions in comparison with the seedlings of the control treatment. In contrast, the least virulent inoculum came from Guerrero; this fungus practically caused no damage, and the inoculated plants were was similar to controls for all variables recorded.

The results of the damage evaluation show that inoculations of Fusarium differentially increased the damage (A, Figure 1) according to inoculum origin. The inoculations also affected the seedling growth (C, Figure 1); the inoculum from Estado de Mexico caused the most reduction in the fresh weight of seedlings and reductions in the length of the roots and aerial portions. The inocula from Guerrero and Oaxaca caused the least damage to the seedlings.

Table 2. Significance of average squares from the variance analysis of seven variables used to measure the effect of six sources of Fusarium spp. inocula in maize landrace populations.

\begin{tabular}{|c|c|c|c|c|c|c|c|}
\hline \multirow{2}{*}{ Sources of variance } & \multirow{2}{*}{$\begin{array}{c}\text { Severity of } \\
\text { damage }\end{array}$} & \multicolumn{2}{|c|}{ Root } & \multicolumn{2}{|c|}{ Seedling } & \multicolumn{2}{|c|}{ Total weight } \\
\hline & & Length & Weight & Length & Weight & Fresh & Dry \\
\hline Blocks & $21.90^{* *}$ & $6122.47^{* *}$ & $5.46^{\star *}$ & $10357.58^{*}$ & $9.51^{\star *}$ & $12.71^{\star *}$ & $0.87^{\star *}$ \\
\hline Inocula (In) & $23.77^{\star *}$ & $1142.36^{* *}$ & $12.03^{\star *}$ & $671.18^{\star *}$ & $8.63^{\star *}$ & $39.45^{\star *}$ & $0.21^{\star *}$ \\
\hline Maize populations (Po) & $0.24^{*}$ & $174.33^{\star *}$ & $1.61^{\star \star}$ & $251.17^{\star \star}$ & $3.46^{\star *}$ & $8.70^{\star *}$ & $0.21^{\star *}$ \\
\hline In- $\mathrm{x}-\mathrm{Po}$ & $0.14^{\mathrm{ns}}$ & $48.67^{\mathrm{ns}}$ & $0.23^{\mathrm{ns}}$ & $18.64^{\mathrm{ns}}$ & $0.23^{\mathrm{ns}}$ & $0.71^{\mathrm{ns}}$ & $0.03^{*}$ \\
\hline Error & 0.17 & 62.40 & 0.30 & 24.08 & 0.27 & 0.91 & 0.03 \\
\hline Coeff. of variation (\%) & 24.0 & 33.0 & 38.0 & 22.0 & 30.0 & 30.0 & 41.0 \\
\hline
\end{tabular}

${ }^{\mathrm{ns}}$ Not significant $(p>0.05) ;{ }^{* *}$ Significant at $p \leq 0.05$ and $p \leq 0.01$, respectively. 


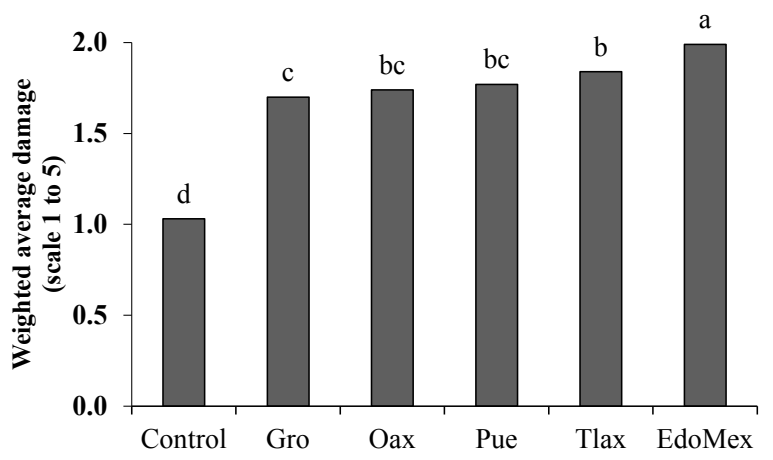

(a)

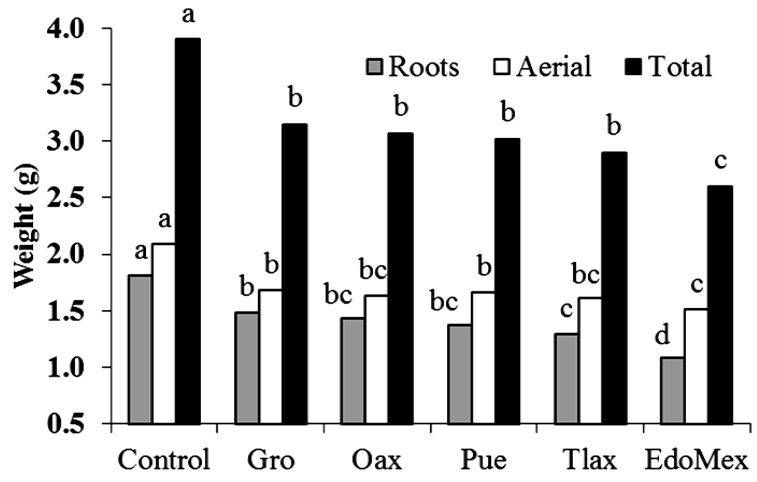

(b)

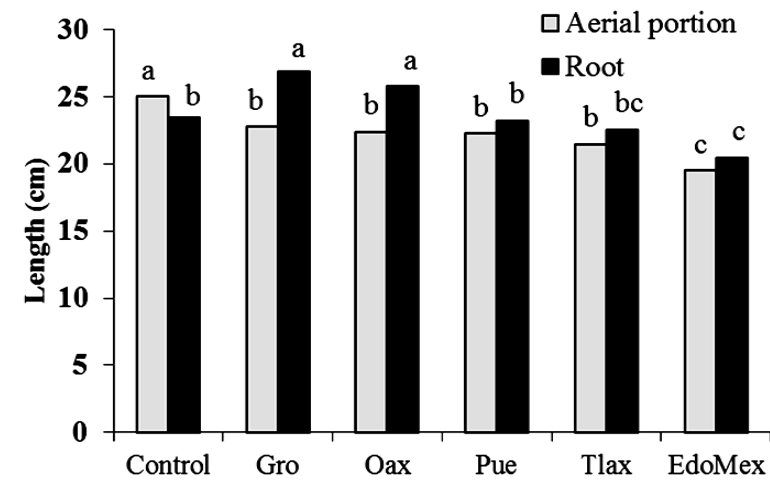

(c)

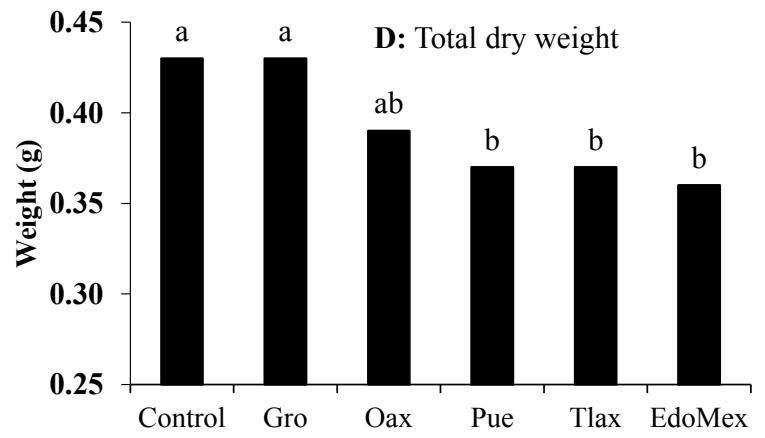

(d)

Figure 1. Effect of inocula of Fusarium spp. from different geographic origins on the average weight and length of seedlings of maize populations. Averages with the same letter are not different significantly (Tukey's test, $p>0.05$ ). (a) Visual damage from Fusarium spp; (b) Fresh weight; (c) Length of root and aerial portion; (d) Total dry weight. 


\subsection{Severity of Damage to Maize Landrace Populations}

All seedlings that germinated on substrate with inocula had visible damage and reduced growth, regardless of the geographic origin of the inoculum. This indicates to a certain point that in all Fusarium spp. isolates there are genes for the synthesis of enzymes that enhance cellular wall degradation of maize seedlings. This fact was observed by quantifying the severity of damage where a wide variation in responses was observed, from seedlings with minimum to maximum damage - the latter being related to severe root rot. The varied responses were an indicator of the degree of virulence of the pathogens and the polygenic nature of resistance to Fusarium spp. in maize. In this context, two blocks of populations were separated, some of them with less damage and others with high damage, in which the latter were associated with reduced growth and development of seedlings (Table 3, Figure 2).

In general, an inverse correlation was determined between seedling growth and development and the severity of damage caused by Fusarium. Specifically, a significant negative correlation was calculated between both root length $(\mathrm{r}=$ -0.45 , Student's t-test $p<0.01)$ and weight $(\mathrm{r}=-0.44$, Student's t-test $p<0.01)$ and the weighted average of damage caused by Fusarium. Among the popula-

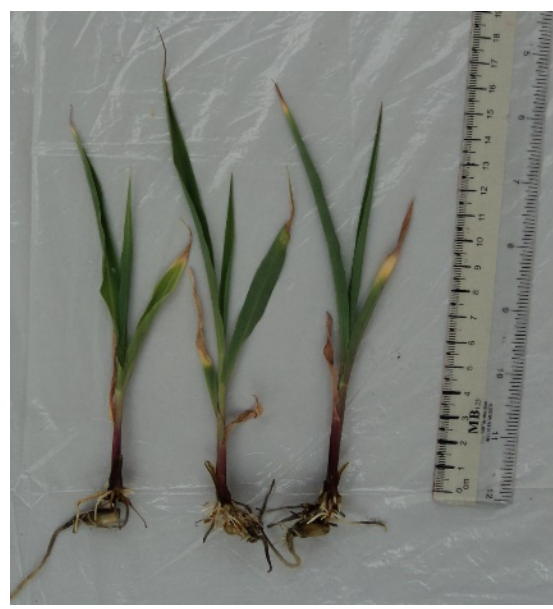

(a)

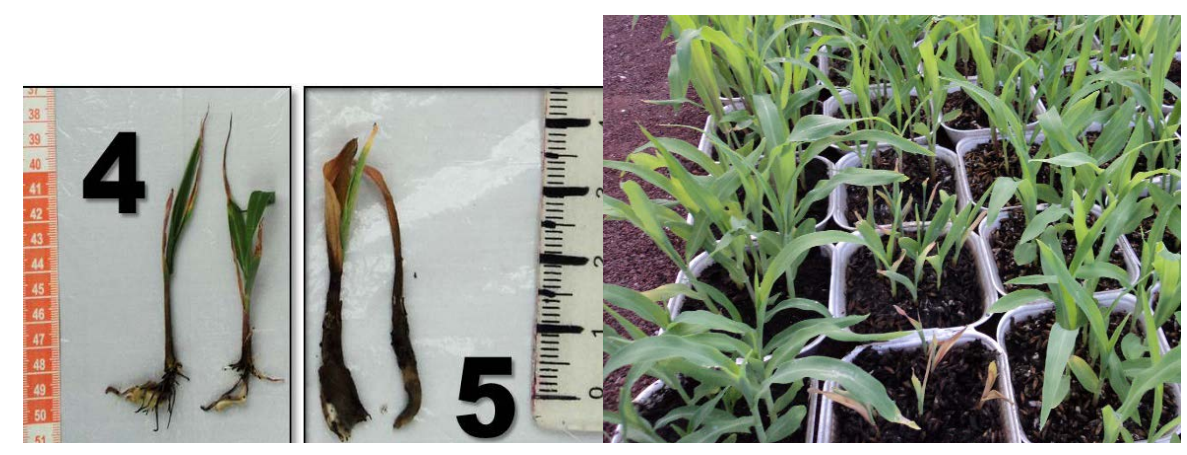

(c)

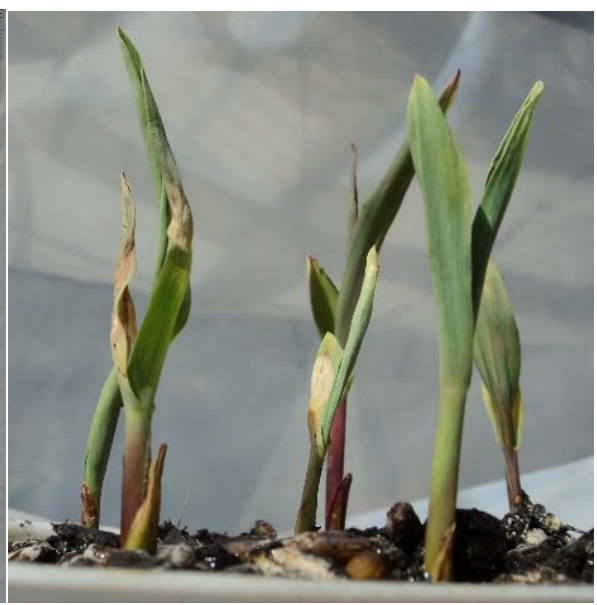

(b)

(d)

Figure 2. Reaction of maize seedlings to inoculation of Fusarium spp., a) and b) variation of reactions in damage; d) severe damage and death of seedlings; and d) reaction differential among maize landrace. 
Table 3. Maize populations with low and high averages of damage in response to Fusarium inoculations regarding seedling growth and development.

\begin{tabular}{|c|c|c|c|c|c|c|c|}
\hline \multirow[b]{2}{*}{ ID, Inoculum origin } & \multirow{2}{*}{$\begin{array}{c}\text { Severity of } \\
\text { damage }\end{array}$} & \multicolumn{2}{|c|}{ Roots } & \multicolumn{2}{|c|}{ Seedlings } & \multicolumn{2}{|c|}{ Total weight (g) } \\
\hline & & $\begin{array}{c}\text { Length } \\
(\mathrm{mm})\end{array}$ & $\begin{array}{l}\text { Weight } \\
\text { (g) }\end{array}$ & $\begin{array}{c}\text { Length } \\
(\mathrm{mm})\end{array}$ & $\begin{array}{l}\text { Weight } \\
\text { (g) }\end{array}$ & Fresh & Dry \\
\hline 41, Estado de Mexico & 1.59 & 20.97 & 1.28 & 24.37 & 1.76 & 3.04 & 0.43 \\
\hline 57, Tlaxcala & 1.61 & 25.68 & 1.60 & 25.74 & 2.03 & 3.59 & 0.43 \\
\hline 03, Tlaxcala & 1.64 & 23.60 & 1.50 & 26.30 & 1.71 & 3.21 & 0.32 \\
\hline 24 , Guerrero & 1.66 & 27.68 & 1.63 & 22.50 & 2.33 & 3.96 & 0.59 \\
\hline 25 , Guerrero & 1.66 & 25.33 & 1.56 & 22.00 & 2.37 & 3.91 & 0.58 \\
\hline 45, Estado de Mexico & 1.67 & 26.20 & 1.58 & 24.23 & 1.82 & 3.40 & 0.43 \\
\hline 50, Puebla & 1.67 & 24.55 & 1.68 & 21.05 & 1.83 & 3.50 & 0.40 \\
\hline 39, Tlaxcala & 1.67 & 25.32 & 1.17 & 23.16 & 1.39 & 2.54 & 0.30 \\
\hline 49, Puebla & 1.67 & 24.74 & 1.71 & 21.21 & 1.73 & 3.45 & 0.39 \\
\hline 46, Estado de Mexico & 1.68 & 27.32 & 1.69 & 25.53 & 1.82 & 3.52 & 0.38 \\
\hline 37, Tlaxcala & 1.69 & 20.63 & 1.19 & 23.71 & 1.63 & 2.82 & 0.39 \\
\hline 21, Guerrero & 1.69 & 26.15 & 1.58 & 22.55 & 2.14 & 3.71 & 0.55 \\
\hline 51, Estado de Mexico & 1.69 & 27.21 & 1.80 & 24.00 & 2.24 & 4.04 & 0.51 \\
\hline 47, Estado de Mexico & 1.70 & 26.32 & 1.56 & 27.00 & 1.87 & 3.43 & 0.43 \\
\hline 38, Puebla & 1.90 & 20.20 & 1.01 & 21.80 & 1.39 & 2.39 & 0.28 \\
\hline 09, Oaxaca & 1.91 & 21.93 & 1.34 & 18.40 & 1.35 & 2.67 & 0.34 \\
\hline 14, Tlaxcala & 1.91 & 25.05 & 1.61 & 24.88 & 1.90 & 3.50 & 0.46 \\
\hline 26, Oaxaca & 1.91 & 24.30 & 1.27 & 21.18 & 1.30 & 2.58 & 0.31 \\
\hline 44, Estado de Mexico & 1.91 & 16.71 & 0.94 & 18.36 & 1.56 & 2.49 & 0.50 \\
\hline 34, Oaxaca & 1.93 & 19.61 & 0.67 & 14.89 & 0.91 & 1.58 & 0.26 \\
\hline 11, Tlaxcala & 1.96 & 24.92 & 1.38 & 24.08 & 1.52 & 2.87 & 0.33 \\
\hline 10, Oaxaca & 1.97 & 23.85 & 1.33 & 18.63 & 1.27 & 2.60 & 0.31 \\
\hline 30, Oaxaca & 1.99 & 21.45 & 0.92 & 15.00 & 1.11 & 2.02 & 0.29 \\
\hline 12, Tlaxcala & 2.02 & 23.93 & 1.57 & 24.73 & 1.61 & 3.17 & 0.38 \\
\hline 15, Puebla & 2.02 & 23.74 & 1.38 & 23.89 & 1.64 & 3.02 & 0.39 \\
\hline 13, Tlaxcala & 2.03 & 18.60 & 0.84 & 16.85 & 1.03 & 1.86 & 0.29 \\
\hline 04, Tlaxcala & 2.04 & 19.75 & 1.16 & 21.75 & 1.71 & 2.86 & 0.40 \\
\hline 08, Estado de Mexico & 2.05 & 22.03 & 1.58 & 24.95 & 2.62 & 4.19 & 0.60 \\
\hline 56, Estado de Mexico & 2.09 & 16.50 & 0.84 & 18.64 & 1.32 & 2.16 & 0.34 \\
\hline DSH-Tukey $(p<0.05)$ & 0.55 & 10.75 & 0.69 & 6.21 & 0.68 & 1.22 & 0.27 \\
\hline
\end{tabular}

tions identified with most reduced root length and major damage were the maize populations collected in Tlaxcala and Estado de Mexico and some populations from Guerrero, Oaxaca and Puebla. However, other groups of populations from the Estado de Mexico, Guerrero, Oaxaca and Puebla also showed more seedling growth and development. This finding means that we can find both tolerant and 
susceptible populations in the same region. Therefore, in term of plant breeding, there is germplasm in each region to start a breeding program. In this context, it was possible to classify the maize populations as a function of their reaction to the most virulent inocula, such as those from Estado de Mexico and Tlaxcala (Figure 3). Then, the populations with minor damage were considered phenotypically tolerant because all of them presented some damage level.

\subsection{Interaction between Maize Origin and Origin of Fusarium spp. Inocula}

There was no relationship between the origin of the maize populations and the origin of the inocula evaluated. Nevertheless, the maize populations and inoculum sources were cobs from the same harvested parcel and farmer that likely survived due to coevolution. The results show independence between the tolerance in the maize populations and the origin of the inocula evaluated, and it was observed that the populations from one state were as susceptible to Fusarium inocula from the same state well as to Fusarium of other origins. For example, the populations from Tlaxcala were severely affected by inoculations from that state. In contrast, populations with certain tolerance regularly presented tolerance to different inoculum sources and origins (Table 4).

\section{Discussion}

The evaluation of damage indicated that the seedlings from all the maize populations were affected by all the isolates. Even when the gathered maize and the isolate came from the same geographic region, no tolerance or possible resistance to the isolate was observed. However, variation in damage observed indi-

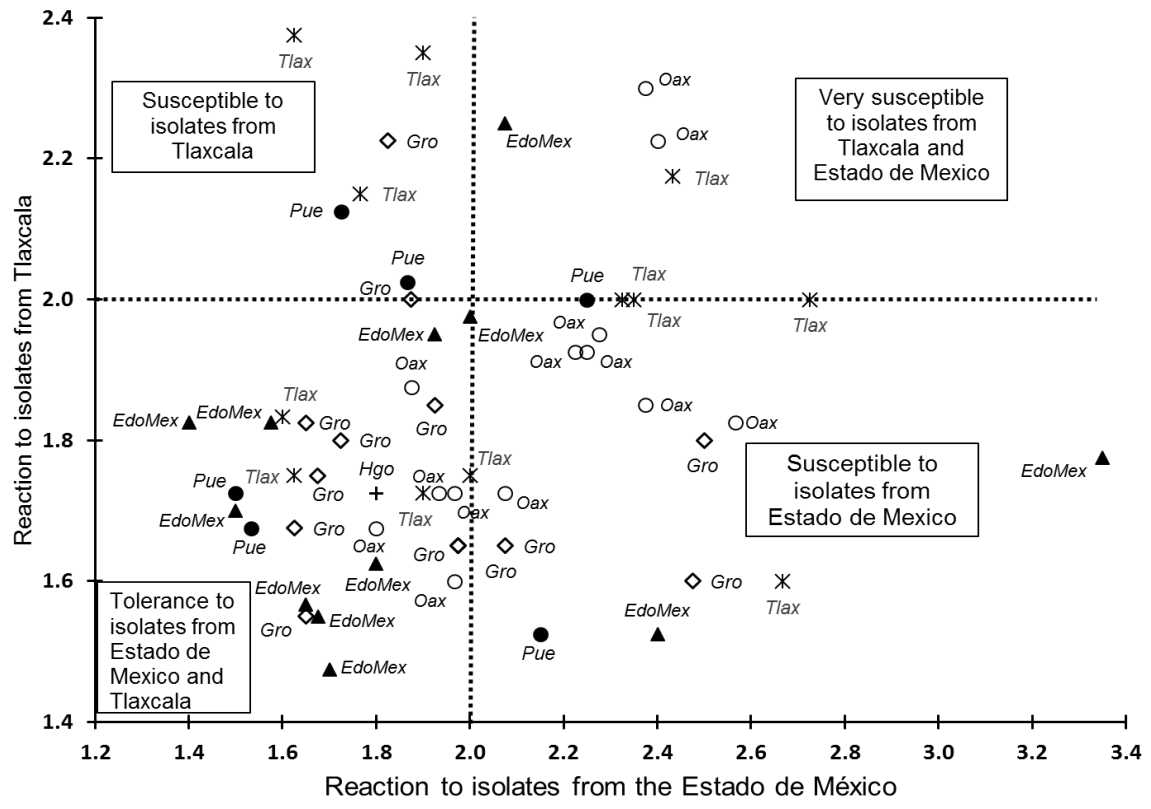

Figure 3. Distribution of maize landrace populations as a function of the reaction to damage to seedlings caused by inoculations of isolates from Estado de Mexico and Tlaxcala (Tukey's test, $p<0.05$ ). 
Table 4. Weighted averages of damage to seedlings from maize populations grouped in three typifications of damage as a response to Fusarium from different geographic origins.

\begin{tabular}{|c|c|c|c|c|c|}
\hline \multirow{2}{*}{ Origin of populations (n) } & \multicolumn{5}{|c|}{ States of origin of the inocula evaluated } \\
\hline & Mexico & Guerrero & Oaxaca & Puebla & Tlaxcala \\
\hline \multicolumn{6}{|c|}{ a) Slight damage ( $<2$ on the damage scale for all the inocula) } \\
\hline Estado de Mexico (6) & $1.75^{\dagger}$ & 1.61 & 1.71 & 1.70 & 1.64 \\
\hline Guerrero (7) & 1.80 & 1.68 & 1.76 & 1.65 & 1.73 \\
\hline Oaxaca (5) & 1.91 & 1.78 & 1.77 & 1.70 & 1.72 \\
\hline Puebla (2) & 1.52 & 1.68 & 1.65 & 1.78 & 1.70 \\
\hline Tlaxcala (3) & 1.71 & 1.51 & 1.60 & 1.61 & 1.77 \\
\hline Average & 1.74 & 1.65 & 1.70 & 1.69 & 1.71 \\
\hline \multicolumn{6}{|c|}{ b) Moderate damage ( $=2$ on the damage scale in at least one inoculum) } \\
\hline Estado de Mexico (3) & 1.93 & 1.65 & 1.70 & 2.08 & 1.95 \\
\hline Guerrero (6) & 2.06 & 1.68 & 1.83 & 1.70 & 1.83 \\
\hline Oaxaca (6) & 2.29 & 1.68 & 1.73 & 1.74 & 1.94 \\
\hline Puebla (2) & 2.01 & 1.76 & 1.63 & 1.68 & 1.78 \\
\hline Tlaxcala (5) & 1.99 & 1.65 & 1.64 & 1.80 & 2.05 \\
\hline Average & 2.06 & 1.68 & 1.71 & 1.80 & 1.91 \\
\hline \multicolumn{6}{|c|}{ c) Severe damage ( $>2$ on the damage scale in two or more inocula) } \\
\hline Estado de Mexico (5) & 2.48 & 1.83 & 1.88 & 1.94 & 2.00 \\
\hline Oaxaca (2) & 2.39 & 1.81 & 1.90 & 1.81 & 2.04 \\
\hline Puebla (2) & 1.99 & 1.83 & 1.93 & 2.01 & 2.06 \\
\hline Tlaxcala (4) & 2.46 & 1.83 & 1.76 & 1.91 & 2.04 \\
\hline Average & 2.33 & 1.83 & 1.87 & 1.92 & 2.04 \\
\hline
\end{tabular}

${ }^{\dagger}$ weighted average of damage in each subgroup of origin and isolate.

cates that it is feasible to differentiate maize populations by their degree of susceptibility to Fusarium spp. and isolates by their degree of virulence, which is appropriate for germplasm evaluation and selection. There were no significant differences $(p>0.05)$ in the interaction between maize populations and the source of the inoculum (Po $\times$ In) in the variables evaluated except for total dry weight; it can be inferred that the inocula and maize populations are independent. In this regard, it should be noted that populations possibly did not show any direct association with any inoculum that would result in greater resistance or tolerance due to the mixture of isolates, since it is not known whether one species dominates over another or whether there could have been synergy between them that would result in greater virulence.

It is appropriate to note that the virulence of phytopathogenic fungi depends on environmental conditions favorable to their multiplication. For example, $F$. graminearum must synthesize enzymes and proteins that degrade the cell wall as well as generate and release mycotoxins [32]. Once degradation of the cell wall begins, the damage increases. In this study, root darkening and rot were observed in seedlings that grew on pathogenic inocula, which distinguishes them 
from healthy seedlings (with no inoculum).

Reduction in root length and weight as an effect of infection/colonization of the pathogen can lead to problems in crop establishment, resulting in seedlings that do not develop properly or those even death due to the systemic transmission of $F$. verticillioides from the seed to the seedling and stem [33]. The wide variability of reactions between maize populations and the incidence of Fusarium spp. indicate that it is possible to select populations with very little or no damage related to the possible presence of resistance and/or tolerance genes in the maize landrace populations. Furthermore, various studies indicate that roots infected with $F$. verticillioides accumulate mycotoxins, such as fumonisin FB1, and can cause necrosis or death of the invaded tissue [34] [35], which was probable for the populations that presented higher damage and exhibited poor growth in this study. This can be said even though the genetic mechanism of resistance present in the maize collections evaluated is not known and can only be evaluated by phenotypic responses.

The results obtained show part of the potential damage from the Fusarium spp. fungus to maize landrace seedlings from different geographic origins. In this study, the most virulent isolates were from Estado de Mexico and Tlaxcala, and these isolates were useful in discriminating maize populations of different geographic origin based on their Fusarium reaction. High variation was also observed in the response to the severity of damage among maize populations in each state. Thus, it is possible to select populations with no visible damage, first in the evaluation of seedlings [36] and later in the ear, as has been done previously [9] [14].

The presence of Fusarium spp. in fields where maize is cultivated is important because of the accumulation of mycotoxins that are found in stored grain [29] from which a wide variety of food products are prepared, thereby posing a risk to human and animal health. The evidence of the coexistence of maize-Fusarium spp. highlights the need to identify maize genotypes or populations resistant to the infection and accumulation of toxins. Consequently, proving resistance or susceptibility in seedlings can be used to discriminate a large number of maize varieties or populations because it makes possible both differentiating some degree of expression of the disease in the vegetative phase in a short period and predicting the behavior regarding germination and survival of individuals in the field [36]. However, although there were no significant interactions between maize populations and inocula, the populations from each geographic origin were classified into three types based on severity of damage: slight, moderate and high, which suggests coevolution between maize and Fusarium spp. through mutual selection pressures, as mentioned by Ehrlich and Raven [37] in the case of closely related species.

\section{Conclusions}

There is variation in the degree of virulence of isolates of Fusarium spp. depending on their geographic origin. As seedlings, maize populations respond 
differently to pathogens from different geographic sources, which indicates some degree of resistance to Fusarium spp. in populations that do not show any visible damage. In the pathosystem of maize landrace populations-Fusarium spp. inocula evaluated, there were no significant interactions that would suggest a direct association between species from the same geographic origin.

\section{Acknowledgements}

We thank Dr. Porfirio Ramírez Vallejo ${ }^{\dagger}$ (Q. E. P. D.) for his teaching and contributions to this study.

\section{References}

[1] Wang, H., Wei, H., Ma, J. and Luo, X. (2000) The Fumonisin $B_{1}$ Content in Corn from North China, a High-Risk Area of Esophageal Cancer. Journal of Environmental Pathology, Toxicology and Oncology, 19, 139-141.

[2] Williams, L.D., Glenn, A.E., Bacon, C.W., Smith, M.A. and Riley, R.T. (2006) Fumonisin Production and Bioavailability to Maize Seedlings Grown from Seeds Inoculated with Fusarium verticillioides and Grown in Natural Soils. Journal of Agricultural and Food Chemistry, 54, 5694-5700. https://doi.org/10.1021/jf0610209

[3] Leyva-Madrigal, K.Y., Larralde-Corona, C.P., Calderón-Vázquez, C.L. and Maldonado-Mendoza, I.E. (2014) Genome Distribution and Validation of Novel Microsatellite Markers of Fusarium verticillioides and Their Transferability to Other Fusarium Species. Journal of Microbiological Methods, 101, 18-23.

[4] Balconi, C., Berardo, N., Locat-Elli, S., Lanzanova, C., Torri, A. and Dedaelli, R. (2014) Evaluation of Ear Rot (Fusarium verticillioides) Resistance and Fumonisin Accumulation in Italian Maize Inbred Lines. Phytopathologia Mediterranea, 53, 1426.

[5] Servicio de Información Agroalimentaria y Pesquera (SIAP) (2014) Annual Statistics of the Agricultural Production in Mexico, 2013. Secretaria de Agricultura, Ganadería, Desarrollo Rural, Pesca y Alimentacion, Mexico. http://www.siap.gob.mx/cierre-de-la-produccion-agricola-por-cultivo/

[6] Fernández, S.R., Morales, C.L.A. and Gálvez, M.A. (2013) Importance of Mexican Maize Landraces in the National Diet. An Essential Review. Revista Fitotecnia Mexicana, 36, 275-283.

[7] Trueba, A. (2012) Improved Seeds of Mexican Maize, Productive Potential. Colegio de Postgraduados, Texcoco, $132 \mathrm{p}$.

[8] Luna, B.M., Hinojosa, M.A., Ayala, O.J., Castillo, F. and Mejía, J.A. (2012) Perspectives of the Maize Seed Industry Development in Mexico. Revista Fitotecnia Mexicana, 35, 1-7.

[9] Briones-Reyes, D., Castillo-González, F., Chávez-Servia, J.L., Aguilar-Rincón, V.H., De León-García de Alba, C. and Ramírez-Hernández, A. (2015) Response of Native Maize from Mexicana Highlands to Ear Rot, under Natural Infectation. Agronomía Mesoamericana, 26, 73-85. https://doi.org/10.15517/am.v26i1.16922

[10] Reyes, C.P. (1990) Maize and Crop. AGT-EDITOR S.A., 460 p.

[11] Munkvold, G.P., McGee, D.C. and Carlton, W.M. (1997) Importance of Different Pathways for Maize Kernel Infection by Fusarium moniliforme. Phytopathology, 87, 209-217. https://doi.org/10.1094/PHYTO.1997.87.2.209

[12] González, H., Vázquez, G., Sahagún, J., Rodríguez, P. and Pérez, L. (2007) Grain 
Yields of Maize Genotypes under Rainfed Conditions and Their Relation to Ear Rot. Agricultura Técnica en México, 33, 33-42.

[13] Morales-Rodríguez, I., Yáñez-Morales, M.J., Silva-Rojas, H.V., García-de-losSantos, G. and Guzmán-de-Peña, D.A. (2007) Biodiversity of Fusarium species in Mexico with Ear Rot in Maize, and Their Identification Using a Phylogenetic Approach. Mycopathologia, 163, 31-39. https://doi.org/10.1007/s11046-006-0082-1

[14] Mesterházy, A., Lemmens, M. and Reid, L.M. (2012) Breeding for Resistance to Ear Rots Caused by Fusarium spp. in Maize-A Review. Plant Breed, 132, 1-19. https://doi.org/10.1111/j.1439-0523.2011.01936.x

[15] Fadonhan, F., Hell, K., Marasas, W.F.O. and Wingfield, M.J. (2003) Infection of Maize by Fusarium Species and Contamination with Fumonisin in Africa. African Journal of Biotechnology, 2, 570-579. https://doi.org/10.5897/AJB2003.000-1110

[16] Bottalico, A. (1998) Fusarium Diseases of Cereals, Species Complex and Related Mycotoxin Profiles in Europe. Journal of Plant Pathology, 80, 85-103.

[17] Peraica, M., Radi'c, B., Luci'c, A. and Pavlovi'c, M. (1999) Toxic Effects of Mycotoxins in Humans. Bulletin of the World Health Organization, 77, 654-766.

[18] Gimeno, A. and Martins, M.L. (2011) Mycotoxins and Mycotoxicosis in Animals and Humans. 3rd Edition, Special Nutrients Inc., Miami, 128 p.

[19] Bacon, C.W. and Hinton, D.M. (1996) Symptomless Endophytic Colonization of Maize by Fusarium moniliforme. Canadian Journal of Botany, 74, 1195-1202. https://doi.org/10.1139/b96-144

[20] Agrios, G.N. (2005) Plant Pathology. Elsevier Academic Press, New York, 922 p.

[21] Paliwal, L.R., Granados, G., Lafitte, H.R., Violic, A.D. and Marathée, J.P. (2001) Maize in the Tropics, Plant Breeding and Production. Food and Agriculture Organization of the United Nations (FAO). Plant Production and Protection Serie No. 28. $392 \mathrm{p}$.

[22] Oliver, R.P. and Schweizer, M. (1999) Molecular Fungal Biology. Cambridge University Press, Cambridge, 377 p. https://doi.org/10.1017/CBO9781139163972

[23] Peiretti-Uzal, D.A., Nazar-Lovera, M.C., Biasutti-Valenzano, C.A. and GiordaLerda, L.M. (2007) Susceptibility to Fusarium verticillioides (Sacc.) Nirenberg in the MPB-FCA 856 Corn Population. Agronomía Mesoamericana, 18, 171-176. https://doi.org/10.15517/am.v18i2.5047

[24] Lanubile, A., Bernardi, J., Marocco, A., Logrieco, A. and Paciolla, C. (2012) Differential Activation of Defense Genes and Enzymes in Maize Genotypes with Contrasting Levels of Resistance to Fusarium verticilliioides. Environmental and Experimental Botany, 78, 39-46.

[25] Ahmad, M.F., Shehzad, S., Hussain, K., Khan, S.H. and Sajjad, M. (2014) Influence of Fusarium Moliniforme Inoculation on Heterosis and Heterobeltosis for Agronomic Traits in Maize (Zea mays). International Journal of Agriculture and Biology, 16, 1041-1049.

[26] Pérez-Brito, D., Jeffers, D., González-de-León, D., Khairallah, M., Cortes-Cruz, M., Velasquez-Cardelas G., Aspíroz-Rivero, S. and Srinivasan, G. (2001) QTL Mapping of Fusarium moniliforme Ear Rot Resistance in Highland Maize, Mexico. Agrociencia, 35, 181-196.

[27] Oren, L., Ezrati, S., Cohen, D. and Sharon, A. (2003) Early Events in the Fusarium verticillioides-Maize Interaction Characterized by Using a Green Fluorescent Protein-Expressing Transgenic Isolate. Applied and Environmental Microbiology, 69, 1695-1701. https://doi.org/10.1128/AEM.69.3.1695-1701.2003

[28] Desjardins, A.E., Busman, M., Muhitch, M.J. and Proctor, R. (2007) Complementa- 
ry Host-Pathogen Genetic Analyses of the Role of Fumonisins in the Zea maysGibberella Moniliformis Seedling Interaction. Physiological and Molecular Plant Pathology, 70, 149-160.

[29] García-Aguirre, G. and Martínez-Flores, R. (2010) Fusarium Species from Corn Kernels Recently Harvested and Shelled in the Fields in the Ciudad Serdan Region, Puebla. Revista Mexicana de Biodiversidad, 81, 15-20.

[30] Solano-Báez, A.R., De León-García, C., Valdovinos-Ponce, D.A., Silva-Rojas, H.V. and Soto-Rojas, L. (2011) The Pigmentation of Fusarium verticillioides (Sacc.) as Factor of Virulence in Maize Seedlings. Agronomía Mesoamericana, 22, 297-307. https://doi.org/10.15517/am.v22i2.11803

[31] Statistical Analysis System (SAS) (1999) SAS ${ }^{\circledast}$ Procedures Guide, Version 8. SAS Institute Inc., Cary, 1643 p.

[32] Kikot, G.E., Hours, R.A. and Alconada, T.M. (2009) Contribution of Cell Wall Degrading Enzymes to Pathogenesis of Fusarium graminearum: A Review. Journal of Basic Microbiology, 49, 231-241. https://doi.org/10.1002/jobm.200800231

[33] Wilke, A.L., Bronson, R.C., Tomas, A. and Munkvold, G.P. (2007) Seed Transmission of Fusarium verticillioides in Maize Plants Grown under Three Different Temperature Regimes. Plant Disease, 91, 1109-1115.

https://doi.org/10.1094/PDIS-91-9-1109

[34] Coehlert, D.C., Knutson, C.C. and Vesonder, R.F. (1994) Phytotoxic Effects of Fumonisin B1 on Maize Seedling Growth. Mycopathologia, 127, 117-121.

https://doi.org/10.1007/BF01103067

[35] Baldwin, T.T., Zitomer, N.C., Mitchell, T.R., Zimeri, A.M., Bacon, C.W., Riley, R.T. and Glenn, A.E. (2014) Maize Seedling Blight Induced by Fusarium verticillioides, Accumulation of Fumonisin $\mathrm{B}_{1}$ in Leaves without Colonization of the Leaves. Journal of Agricultural and Food Chemistry, 62, 2118-2125. https://doi.org/10.1021/jf5001106

[36] Bacon, C.W., Hinton, D.M. and Richardson, M.D. (1994) A Corn Seedling Test for Resistance to Fusarium Moniliforme. Plant Disease, 78, 302-305. https://doi.org/10.1094/PD-78-0302

[37] Ehrlich, P.R. and Raven, P.H. (1964) Butterflies and Plants, a Study in Coevolution. Evolution, 18, 586-608. https://doi.org/10.1111/j.1558-5646.1964.tb01674.x

Submit or recommend next manuscript to OALib Journal and we will provide best service for you:

- Publication frequency: Monthly

- 9 subject areas of science, technology and medicine

- Fair and rigorous peer-review system

- Fast publication process

- Article promotion in various social networking sites (LinkedIn, Facebook, Twitter, etc.)

- Maximum dissemination of your research work

Submit Your Paper Online: Click Here to Submit

Or Contact service@oalib.com 